Metal ions whose sulfides develop color were separated from each other by paper chromatography using a solution of ammonium sulfide (commercia! reagent, JIS first class grade chemical) as a developing solvent.

Antimony, tin and arsenic ions migrated with the solvent as their thionates, whereas other ions remained at the original point as their sulfides. Therefore ions of antimony, tin and arsenic were separated from other metal ions by a solution of ammonium sulfide (colorless).

It is rather difficult to separate tin from antimony by paper chromatography. However the separation was completed by using a mixed solution of ammonium polysulfide and pyridine, regardless of their oxidation numbers.

The sample solution contains $5 \mathrm{mg}$ of each metal ion in $1 \mathrm{ml}$ of $6 N \mathrm{HCl}$.

One microliter of the sample solution was spotted with a capillary tube $1 \mathrm{~cm}$ apart from the end of filter paper (Toyo Roshi, No. 50).

The paper was developed up to $5 \mathrm{~cm}$ by the ascending technique for 30 minutes. The volume ratio of ammonium polysulfide to pyridine was $2: 3$. The paper was dried at room temperature, and then the spots of antimony and tin appeared as their sulfides. The $R_{f}$ values of antimony(II, V) and $\operatorname{tin}(\mathrm{II}, \mathrm{IV})$ are 0.28 and 0.94 .

Arsenic can be separated from tin by the same procedure as antimony separated from tin. 'The $R_{f}$ values of $\operatorname{arsenic}(\mathrm{V})$, arsenic(III) and $\operatorname{tin}(\mathrm{II}, \mathrm{IV})$ are 0.12 , 0.36 and 0.94 , respectively.

When a small amount of 2,4,6-collidine was added in the solvent, antimony can be separated from arsenic. The sample solution contains $2 \mathrm{mg}$ of antimony(III, V) with tin(II, IV) and $5 \mathrm{mg}$ of arsenic(III, V) as each metal ion in $1 \mathrm{ml}$ of $6 \mathrm{~N} \mathrm{HCl}$.

The paper was developed up to $7 \mathrm{~cm}$ by the ascending technique for 60 minutes. The solvent used was ammonium polysulfide, pyridine and 2,4,6-collidine in a $35: 55: 10$ volume ratios. The spot of antimony was in contact with that of arsenic(III) but can be distinguished by their color of sulfides.

Consequently, a mixed solution of ammonium polysulfide and pyridine was effective for the paper chromatographic separation of antimony, tin and arsenic ions.

(Received Aug. 23, 1973)

\title{
加熱食塩を用いる二酸化イオウと硫酸ミストの分別定量
}

\author{
吉森 孝良*，野々村 娍** \\ (1973 作 8 月 31 日受理)
}

\begin{abstract}
硫酸ミストは加熱食塩と反応して塩化水素ガスを生ずるが，二酸化イオウは惊实上反応しないことを 利用して，二酸化イオウと硫酸ミストとを分別定量した.

一定量の硫酸ミストは硫酸水素カリウム標準溶液一定量を, 電気归で $800^{\circ} \mathrm{C}$ まで徐々に加熱分解し て発生させた.二酸化イオウ源としては標準ガスを用いた。

まず, 硫酸ミストの吸収剂について検討した結果, 適当といわれている $80 \%$ イソプロピルアルコー ル水溶液は推奨できず，1\% 過酸化水素水とFig. 1 の静電集じて装置を組み合わせたものが最も適当 であった。

硫酸ミストと二酸化イオウとの混合物を $500^{\circ} \mathrm{C}$ に加熱した食塩と反応させた結果，ミストの $90.4 \%$ と, 二酸化イオウの $3.3 \%$ とが塩化水素ガスに置換した. 二酸化イオウ含量が少ないときは, その転化 率は無視できた.

この方法を実際に鉱石焼結炉とボイラー加熱炉の排ガス分析に応用した.
\end{abstract}

\footnotetext{
1 緒 $\overline{\overline{\bar{n}}}$

大気污染成分であるイオウ酸化物のうち，二酸化イオ

* 東京理科大学工学部 : 東京都新宿区神楽坂 1-3

** 現在 東京都立工業技術センター：東京都北区西ケ 丘 3-13-10
}

ウは水に溶けやすく, その定量は比較的容易であるが, ミスト状のものは水に吸収されにくく定量が困難であ る・また，排ガスに拉てを硫酸ミストの処理は必ずし も容易ではない.

一般に煙道排ガス中の三酸化イオウは，全イオウ酸化 物の 1〜5\% であるといわれている1). また，大㸚中で 


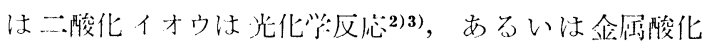
物45)抢よび水分の掕触作朋などによって三酸化イオウ あるいは硫酸ミストに酸化されると考无られているが， 大父小でのイオウ酸化物の反応についてはまだ不明の点 が多く，推測の域を脱していないようである.

イオウ酸化物の分析方法は多数報告されているが，三 酸化イオウまたは硫酸こス卜に限っていえば，大部分は 㞣显分析泣または比濁法によっている(6) -11)18) 21)。 ま た二酸化イオウと三酸化イオウの分別定量の研究も多 く122)-27), 上氾の定量法のほかには電気化学的方法も しばしば用いられる12) 一17).

一般にこれらの方法では，イオウ酸化物を溶液中に捕 集せねばならず，特にミスト状の物啠の吸収に問題があ る. この場合の吸収液として, Flint ${ }^{22)} や$ Corbett $^{24)}$ が 吸収された二酸化イオウの酸化の抑制に，80\% イソプ ロピルアルコール水溶液（以下 $80 \%$ IPA と略記）を用 いて以来, この溶液を似用した䂨究が多いが1889)25)26), その溶液の硫酸ミストの吸收㴒については, その後あま り検討されていないようである。

一方, 硫酸ミス卜を完全に捕集するために, 種々の方 法が考案された. すなわち, 沪過法 18)1928), 溶液に直接 吸収させる方法 ${ }^{1221)}$, 上㲹両者の併用法22)23), 電気集じ 几法21 29), 音波凝集法 ${ }^{30)}$, 吸着法19), 衝突法 ${ }^{31}$ 32) 打よび ほうまつ捕集法(0)などである。これらのうち一般的には 沪過法が行なわれており, 武料ガスをガラスウール20), ガラスフィルター22) 23) 28)33)，アスベストまたは沪紙18)19) なごを通して捕集する方㤼採用されている。しかし， これら沪過法では数 $\mu \mathrm{m}$ 以下の微細粘子の捕集には疑問 が残る・また，Kerrigan ら21) はこの捕集法について電 気集じん装霍, Greenburg-Smith インピンジャ一执よ びシンタードガラスフィルターの 3 者を比較し, 電気集 じえ装置がよいと報㘶し，柳沢ら 29) も電気集じえ装置で ほぼ完全に捕集されることを示した。

一定娜の二酸化イオウや三酸化イオウ（硫酸ミスト） を発生させるカ汒は，分析法の倹讨にあたり最も重要な 開題である。特に硫酸ミストに対しては既知濃度の希硫 酸の一定星を加熱分解与る方法22 23) 28) および二酸化イオ ウ標準ガスを白金触媒で酸化する方法29)などがあるが， これらの酸化物を純䊉な形で得るには種々の問題がある ように思われる。

本研究においては，まずなるべく簡翟な一定量の硫酸 ミスト発少泣として, 硫酸水素坥の熱分解法を検討し た. 次に速埇 ${ }^{34)}$ で報售した, 硫酸ミストと加熱食增を反 応させてこれを盐酸として定量する方法を梌討したの ち, この方法で二酸化イオウと硫酸ミストとの分別定量
を試みた。さらにこの方法を䒠除に鉱石燒結炉排ガスや ボイラー排ガスけのイオウ酸化物の測定にも使用し，い ずれも一応良好な絬果を得たので報告する.

なお，乙の方法は単に分析法としての利用ばかりでな く, 排ガスの処理にも役だつ可能性があると考えられ る.

\section{2 試薬ならびに实験装置:}

\section{1 試 薬}

試薬はすべて特級品を用い，特別な精製は行なわなか った。溶液の調製は以下のとおりである。

硫酸水素カリウム標準溶液 $(0.1 \mathrm{~mol} / 100 \mathrm{~m} l)$ ：硫酸 水素カリウム $13.62 \mathrm{~g}$ を蒸留水で溶解し, 全量を正確に $100 \mathrm{ml}$ にうすめた。

$N / 10$ 抢よび $N / 100$ 水酸化ナトリウム標準溶液 : 水 酸化ナトリウムの濃厚溶液をガラス沪過器を用いて沪過 したのち希釈する方法 ${ }^{35}$ によって調製した。また，これ らはフタル酸水素カリウムで標定した。

$N / 100$ 塩化バリウム標準溶液および硫酸イオン標準 溶液: これらは JIS の方法36)によって調製した。

$N / 10$ 硝酸銀標準溶液, メチルレッドーメチレンブル 一混合指示薬，トリン指示薬拉よびクロム酸カリウム指

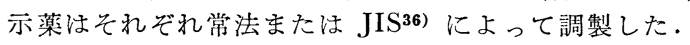

二酸化イオウ標準ガス：東洋酸素(株)製の窒素ガス ベースの標準ガスを使用した（二酸化イオウ含量は 11 ppm，および $1064 \mathrm{ppm}$ の 2 種).

\section{2 装置}

一定量の硫酸ミストを発生させ，これを電気集じえ法 で捕集する装置を Fig. 1 亿示した。燃焼管は長さ 50 $\mathrm{cm}$, 内径 $2 \mathrm{~cm}$ の石英管に図のようにキャップを付けた ものを用いた。吸収びん（I） は内径 $3 \mathrm{~cm}$ ，高さ $10 \mathrm{~cm}$ で吸収液 $40 \mathrm{~m} l$ を入れたとき, ガス導入管上部の水層の 高さは約 $5 \mathrm{~cm}$ であった。電気集じえ装置は交流高圧電 源としてネオンサイン用変圧器を使用し, その電圧はス ライダックで調節した。集じえ装置本体は内径 $2 \mathrm{~cm}$, 高さ $15 \mathrm{~cm}$ のガラス製で内部電極にはタングステン線 （直径 $0.5 \mathrm{~mm}$ ) を, 外部電極としてはガラス管の外側 に銅網を卷いた。この装置の下部から出るガスはさらに 吸收容器 (Fig. 1，No. 7) を通した。

一定量の硫酸ミストを発生させ，乙れを加熱食塩と反 応させる装置は既報34) に示したので省略する.

Fig. 2 亿煙道排ガス中のイオウ酸化物の分析装置を示 す. 石英管は長さ $1 \mathrm{~m}$, 内径 $15 \mathrm{~mm}$, 磁製管は長さ 80 $\mathrm{cm}$, 内径 $25 \mathrm{~mm}$ で, 磁製管の外側にニクロム線をらせ え状に卷き，その上を酸化マグネシウムで被覆し，アス ベスト板を巻いて保温した。ガスメーターは品川製作所 製の WE-1 型の湿式ガスメーターを，吸引ポンプはイ ワキ(株)製のダイヤフラム型のものを，ガラス電極 $\mathrm{pH}$ 計は日立一堀場製 H-5 型を使用した。 


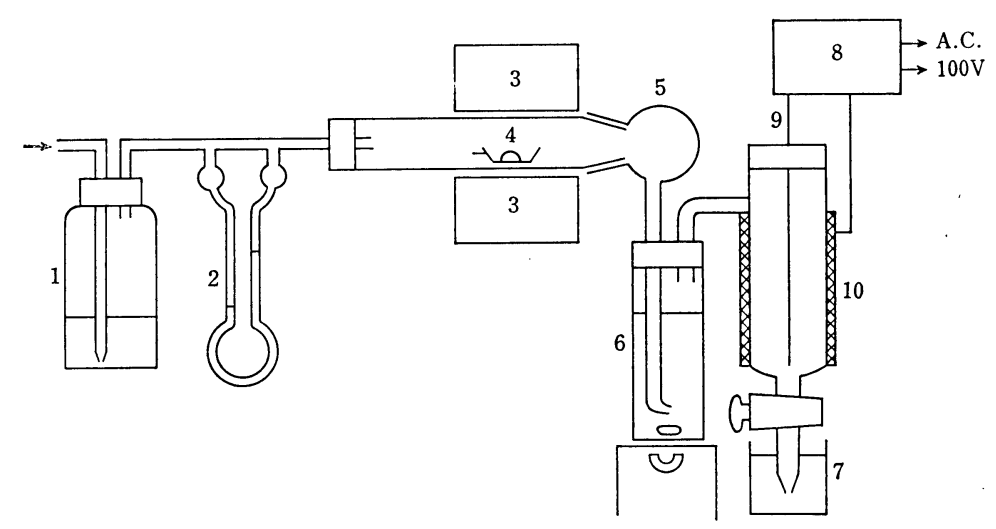

Fig. 1 Apparatus with Cottrell precipitator

1 : conc. $\mathrm{H}_{2} \mathrm{SO}_{4} ; 2$ : Flow meter (liquid paraffin); $3:$ Furnace; $4: \mathrm{KHSO}_{4} ; 5:$ Cap; $6:$ Absorbing bottle I;

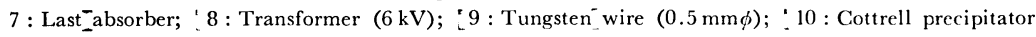

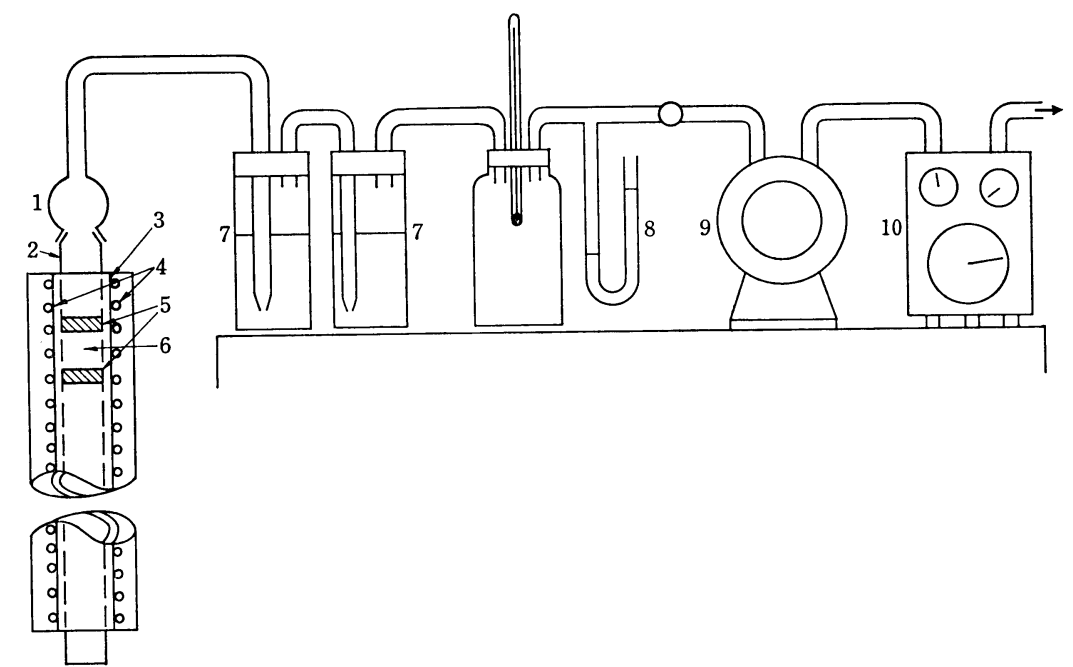

Fig. 2 Apparatus for the determination of sulfur oxides in flue gas

$1:$ Cap; $2:$ Quartz tube; $3:$ Porcelain tube; $4:$ Nichrome wire; $5:$ Quartz wool; $6:$ Sodium chloride ;

$7:$ Absorbing bottles; $8:$ Manometer; $9:$ Pump; $10:$ Gas meter

\section{3 実験方法}

\section{1 一定量の硫酸ミストの発生と捕集}

硫酸水素カリウム標準溶液一定量を $50 \mu l$ のマイクロ シリンジで石英製ボートにとり，これを赤外線電球で乾 燥したのち, Fig. 1 の $300^{\circ} \mathrm{G}$ 以下の電気炉に入れ, そ の温度を約 30 分間で $800^{\circ} \mathrm{C}$ まで上昇させて一定量の 硫酸ミス卜を発生させた. 生成した硫酸ミストは約 700 $\mathrm{m} l / \mathrm{min}$ の窒素ガス気流で吸収液に送り込み, ここで吸 収されずに発生した白煙は Fig. 1 のコットレル式電気
集じん装置で捕集した。集じん電極間の交流電圧は約 $6 \mathrm{kV}$ とした. 試料分解後, キャップ, 吸収びえおよび 集じえ装置の内壁をじゅうぶえに洗浄したのち, 中和滴 定法またはトリンを用いる塩化バリウム滴定法で硫酸を 定量した、ボート中に残留した硫酸カリウムは湓化バリ ウム滴定法で定量し, 試料の分解率を求めた。

\section{2 硫酸ミストおよび二酸化イオウと加熱食塩との} 反応

加熱食塩と硫酸ミストの反応の操作とその検討はすで 
に速報 ${ }^{34)}$ で報紫したので省略する。

加熱食盐と二酸化イオウの反忍の検㖊では，ジフェニ ルチオ尿素を酸素ガス父流中で燃焼したときの生成ガ ス，および市販の二酸化イオウ標準ガスを試料とした. シフェニルチオ尿素は速報 ${ }^{34)}$ に示した装置を用い，酸素 ガス気流中で約 $1000^{\circ} \mathrm{G}$ で燃焼させた：二酸化イオウ 標準ガスは，二酸化イオウ含星が $11 \mathrm{ppm}$ および 1064 ppm のものを使用した. キャリャーガスは，ジフェニ ルチオ尿素のときは酸素ガスを，標準ガスはそのまま通 し，それらの流速は $100 \sim 500 \mathrm{ml} / \mathrm{min}$ の間で一定に保 った．吸収液はジフェニルチオ尿素のときは水を，標準 ガスのときは $1 \%$ 過酸化水素水を用いた. キャップの洗 浄液および吸収びえ中の硫酸と塩酸との量は, 水酸化ナ トリウムおよび硝酸銀の標準溶液で滴定し，全酸量と塩 素イオン量とを求め，その值から算出した。

3.3 加熱食塩を用いる二酸化イオウと 硫酸ミストと の分別定典

速報 ${ }^{34)}$ と同じ装置を用い，3.1 の方法で発生させた一 定量の硫酸ミストと，二酸化イオウ標準ガスとの混合物 を $500^{\circ} \mathrm{C}$ に加熱した食塩と反応させた. キャリャ一ガ スとしては二酸化イオウ標準ガス中の空素ガスを用い, 吸収液は $1 \%$ 過酸化水素水である. 他の操作および塩化 水素ど二酸化イオウとの定量法は 3.2 に示したとおりで ある。

\section{4 加熱食塩法による 煙道排ガス中の二酸化イオウ と硫酸ミストの分別定量}

Fig. 2 に本実験で使用した装置を示した。実験装置を Fig. 2 のように組み立て, 企睢の部分を $500^{\circ} \mathrm{C}$ の一定 温度に保った. 煙道排ガスは約 $1 \mathrm{l} / \mathrm{min}$ の流速で 20 分 間吸引し，加熱食塭と反応させたのち，吸収液に吸収さ せた. 吸収液には $1 \%$ 過酸化水素水を使用した. 吸引し
たガスの体積はガスメーターで测定した.キャップおよ び吸収びえ中の全酸量および塩素イオン量は 3.2 の方法 で定量した.

\section{4 結果と考察}

\section{1 一定量の硫酸ミストの発生と捕集}

一定量の三酸化イオウ（硫酸ミスト）の発生法として は，前述のように多くの方法が報告されているが，本研 究では試料のはかりとりの容易さや分解性を考慮して, ピロ硫酸カリウムおよび硫酸水素カリウムを, 電気炉で 加熱分解する方法を Fig. 1 の装置を用いて 検討した. その結果, 前者ではその化学式から計算した量よりもは るかに少量の硫酸ミストしか得られなかったが, 後者で は試料採取量から計算した值とほぼ等しい量の硫酸々ス トが得られた。またこれの加熱条件としてては，速報 ${ }^{34) て ゙ ~}$ 示したように, $300^{\circ} \mathrm{C}$ 以下の温度で電気炉にそう入し, 30 分間で $800^{\circ} \mathrm{C}$ まで徐々に加熱分解するのが最も適当 であった．試料を完全に分解させると同時に，発生した 硫酸こストが燃焼管内に付着するのを防ぐためには, $800^{\circ} \mathrm{C}$ まで加熱する必要があった。

各種の吸収溶媒および吸収器具について, 硫酸ミスト の捕集率を比較検討した結果を Table I に示す. 吸収 溶媒は蒸留水，1\% 過酸化水素水または $80 \%$ IPA につ いて検討した. 吸収器具のキャップにはガスの吹き出し 口に，引き伸ばしたガラス管を切ったままのインピンジ ャ一型のもの（吹き出し口径約 $1 \mathrm{~mm}$ ), G-2 のガラス フィルターを吹き出し口に付けたもの，または G-1 ガ ラスフィルター付きの吸収びえ（容量 $250 \mathrm{ml}$ ) の 3 種 について検討した. また，キャップ部の硫酸（または三 酸化イオウ）の定量は次のようにした。すなわらガスを 流しながら吸収びんを下げて取りはずし，キャップ下部 の外側を少量の水で吸収液に洗い込んだのち, キャップ 内壁に付着した硫酸を別のビーカーに水で洗い出し，こ

Table I Comparisons of the type of absorbing bottle and of the absorbent for determination of sulfuric acid mist

\begin{tabular}{|c|c|c|c|c|c|c|c|}
\hline \multirow{2}{*}{ Absorbing bottle } & \multirow{2}{*}{ Absorbent } & \multirow{2}{*}{$\underset{(\mathrm{mg})}{\mathrm{KHSO}_{4} \text { taken }}$} & \multicolumn{5}{|c|}{$\mathrm{H}_{2} \mathrm{SO}_{4}$ collected $(\%)$} \\
\hline & & & Cap & Bottle I $\dagger$ & $\begin{array}{l}\text { Cottrell type } \\
\text { precipitator }\end{array}$ & $\begin{array}{c}\text { Last } \\
\text { absorber } \dagger\end{array}$ & Total sum \\
\hline $\begin{array}{l}80 \mathrm{ml} \text { bottle with } \\
\text { impinger }\end{array}$ & $\begin{array}{l}\mathrm{H}_{2} \mathrm{O} \\
1 \% \mathrm{H}_{2} \mathrm{O}_{2} \\
80 \% \mathrm{IPA}\end{array}$ & $\begin{array}{c}3.1 \sim 9.5 \\
6.8 \\
4.8 \sim 9.8\end{array}$ & $\begin{array}{l}38 \sim 43 \\
31 \sim 47 \\
47 \sim 60\end{array}$ & $\begin{array}{r}21 \sim 25 \\
6 \sim 12 \\
2 \sim 6\end{array}$ & $\begin{array}{l}28 \sim 31 \\
45 \sim 52 \\
18 \sim 28\end{array}$ & $\begin{array}{l}1 \sim 4 \\
1 \sim 3 \\
3 \sim 6\end{array}$ & $\begin{array}{l}89 \sim 103 \\
96 \sim 101 \\
78 \sim 87\end{array}$ \\
\hline $\begin{array}{l}250 \mathrm{~m} l \text { bottle with } \\
\text { G-1 filter }\end{array}$ & $\begin{array}{l}\mathrm{H}_{2} \mathrm{O} \\
1 \% \mathrm{H}_{2} \mathrm{O}_{2} \\
80 \% \text { IPA }\end{array}$ & $\begin{array}{l}6.7 \\
6.8 \\
6.7\end{array}$ & $\begin{array}{l}37 \sim 50 \\
41 \sim 49 \\
30 \sim 43\end{array}$ & $\begin{array}{l}14 \sim 25 \\
11 \sim 17 \\
12 \sim 19\end{array}$ & $\begin{array}{l}31 \sim 37 \\
33 \sim 43 \\
40 \sim 44\end{array}$ & $\begin{array}{l}1 \sim 3 \\
0 \sim 1 \\
1 \sim 5\end{array}$ & $\begin{array}{l}93 \sim 100 \\
96 \sim 100 \\
98 \sim 102\end{array}$ \\
\hline $\begin{array}{l}80 \mathrm{~m} l \text { bottle with } \\
\mathrm{G}-2 \text { filter }\end{array}$ & $\begin{array}{l}\mathrm{H}_{2} \mathrm{O} \\
1 \% \mathrm{H}_{2} \mathrm{O}_{2} \\
80 \% \text { IPA }\end{array}$ & $\begin{array}{l}6.7 \\
6.8 \\
6.7\end{array}$ & $\begin{array}{l}43 \sim 46 \\
38 \sim 49 \\
42 \sim 64\end{array}$ & $\begin{array}{c}13 \sim 20 \\
10 \sim 18 \\
3 \sim 11\end{array}$ & $\begin{array}{l}28 \sim 35 \\
32 \sim 45 \\
27 \sim 50\end{array}$ & $\begin{array}{l}0 \sim 2 \\
1 \sim 3 \\
1 \sim 2\end{array}$ & $\begin{array}{l}87 \sim 98 \\
96 \sim 100 \\
92 \sim 102\end{array}$ \\
\hline
\end{tabular}

$\dagger$ c.f. Fig. 1 
の洗液を中和滴定した. Table I の結果から,一般にキ ヤップ内壁の付着率が吸収びんIよりもかなり大きいこ とがわかる．これは硫酸水素カリウムが $210^{\circ} \mathrm{C}$ で分解 して発生した水分がキャップの部分に凝縮し, 次に 300 ${ }^{\circ} \mathrm{G}$ 以上で発生した三酸化イオウがその吸湿性のために キャップ部の水分と結合したり, また最初から硫酸ミス トとして発生したものが，キャップの低温部分に付着し たものと思われる。また，吸収びんIに吸収されずに発 生した硫酸ミストは，コットレル型電気集じえ装置でほ ぼ完全に捕集されるが，最後の吸収びえにおける定量結 果が示すように, 微量の漏れが認められた.これは試料 が $400^{\circ} \mathrm{C}$ 付近で急激に分解したとき，一時的に高濃度 の三酸化イオウ（硫酸こスト）が発生した場合におこ り，この程度の電気集じん装置では，三酸化イオウが高 濃度のときには捕集できないこともあることを示してい る。また，どの吸収びえを用いたときも，80\% IPA の 吸収率は水に比較して一般にかなりわるかった。同時に $1 \%$ 過酸化水素水を用いたときの結果から考えて, 硫酸 水素カリウムは硫酸乏スト源として一応利用できるもの と考えられる。なお，ボート中の残留物を分析した結 果, 試料の分解率はほぼ 100\% であった.

Table I においてガラス管の先端を引き伸ばした簡単 なインピンジャーを用いたときと，G-1 または G-2 の ガラスフィルターを，ガス噴出口の先端に付けた吸収び えを用いたときとでは，それぞれの吸収溶媒における各 部分の付着または捕集率に大差は認められなかった。す なわち, キャップ内壁の付着率が吸收びんI の捕集率よ りも大きく，びえ I の吸収率および電気集じん装置の捕 集率の間にも大差は認められない。このことから, 吸収 びえに発生する気ほうを多少細かくする程度では, 溶液 への吸収率をよくすることは困難であるといえる.

キャップの露出部分をリボンヒーターで加熱し, さら にアスベストで保温して $300 \sim 320^{\circ} \mathrm{C}$ に保って硫酸えス トの付着を少なくしょうとしたが，キャップ内壁の付着 率はほとんど变わらなかった。ただし，キャップの保温 された部分と保温されない部分の付着率を知るために， 取りはずしたキャップの下部の保温されない部分だけを 水中に上下させて, その内面の付着物だけを溶かし出し た溶液と，保温されていたキャップ上部を洗浄した溶液 との両方に含まれる酸を別々に分析してみると，保温 された部分の付着率は 0〜8\% で少なく，残りの大部分 は保温されなかった部分に付着していることがわかっ た.

Flint ら ${ }^{22)}$ が二酸化イオウの酸化抑制剂として $80 \%$ IPA を用いて以来，これが三酸化イオウの吸收溶媒と
して適当なものといわれるが26)37)，それは誤りであるこ とが Table I の 80\% IPA の吸収率からもわかる. 一 方，水または $1 \%$ 過酸化水素水はほとんど同程度の吸収 能力を示した.

\section{2 加熱食塩を用いる硫酸ミストの捕集}

速報34)で示したように，硫酸ミストが $450^{\circ} \mathrm{C}$ の食塩と 反応したとき，その塩化水素ガスへの転化率は $90 \%$ 程度 であった。その低值になる理由としては, Gmelin ${ }^{38)}$ に よると食塩と硫酸との反応において, 硫酸水素ナトリウ ムと塩化水素ガスの生成反応では約 $150^{\circ} \mathrm{C}$ で 66〜 70\% の塩化水素ガスが回収されるが，生成した硫酸水素ナト リウムの解離反応を完全に進めるには， $800^{\circ} \mathrm{C}$ まで加熱 して食塩を溶融する必要があるという，本研究では 450 $\sim 500^{\circ} \mathrm{G}$ に加熱した食塩と反応させたために，一部生成 した硫酸水素ナトリウムが完全に解離していなかったも のと考光られる.なお，食塩を $800^{\circ} \mathrm{C}$ まで加熱して，溶 融ないしそれに近い状態にすると，石英燃焼管がひび割 れをおこしたり，もろくなったりしたままた，あまり高 温に加熱すると, 硫酸の一部が解離して二酸化イオウに なるおそれもあるので，食塩は $500^{\circ} \mathrm{C}$ に保つことにし た。

\section{3 二酸化イオウと加熱食塩との反応}

二酸化イオウも加熱食塩と反応して塩化水素ガスを生 ずるといわれているので38)，その程度と挙動について検 討した.

一定量の二酸化イオウを得るためにはイオウの有機元 素分析用標準物質であるスルホナールを燃焼させる方 法39)打よび亜硫酸水素ナトリウムと塩酸または硫酸を反 応させる方法33)などが用いられているが，ここではまず 純粋なものを得やすく, かつ分子量も大きいジフェニル チオ尿素の利用を試みた。すなわち，その一定量を 既 報34の装置で酸素ガス気流中で約 $1000^{\circ} \mathrm{C}$ で燃焼させる 方法を検討したが，生成した二酸化イオウの $6 〜 12 \%$ が塩化水素ガスに置換されていた. これは従来の報告に ああるように，ジフェニルチオ尿素の燃焼によって二酸 化イオウと同時に三酸化イオウあるいは硫酸 ストが生 成したためと思われる39)のでその使用は断念した。

次に二酸化イオウ標準ガスを窒素ガス気流中で $500^{\circ} \mathrm{C}$ に加熱した食塩と反応させる方法を採用した. この方法 によって得た結果を Table II に示す. Table II に打 いて上段の 5 個は流入ガス中の 全二酸化イオウ量が約 $250 \mu \mathrm{eq}$, 下段の 5 個はそれが約 $500 \mu \mathrm{eq}$ 付近のもので ある. 前者は $1064 \mathrm{ppm}$ の標準ガスを $2.5 \sim 3 l$, 後者 
Table II The amount of chloride ion formed by the reaction of sulfur dioxide and sodium chloride at $500^{\circ} \mathrm{C}$

$\left(\mathrm{SO}_{2}: 1064 \mathrm{ppm}\right)$

\begin{tabular}{|c|c|c|c|c|c|}
\hline $\begin{array}{l}\mathrm{SO}_{2} \text { taken } \\
(\mu \mathrm{eq})\end{array}$ & $\begin{array}{l}\text { Amount of } \\
\text { total acid } \\
(\mu c q)\end{array}$ & $\begin{array}{l}\text { Amount } \\
\text { of } \mathrm{Cl}^{-} \\
(\mu \mathrm{eq})\end{array}$ & \multicolumn{3}{|c|}{$\begin{array}{l}\text { Conversion } \\
\text { ratio }(\%)\end{array}$} \\
\hline 243 & 247 & 7.7 & \multicolumn{3}{|c|}{3.2} \\
\hline 224 & 238 & 8.5 & \multicolumn{3}{|c|}{3.8} \\
\hline 243 & 248 & 7.0 & \multicolumn{3}{|c|}{2.9} \\
\hline 250 & 257 & 9.6 & \multicolumn{3}{|c|}{3.8} \\
\hline 250 & 253 & 9.5 & \multicolumn{3}{|c|}{3.8} \\
\hline & & & mean & 3.5 & $\hat{\sigma}=0.39$ \\
\hline 456 & 462 & 15.6 & \multicolumn{3}{|c|}{3.4} \\
\hline 533 & 538 & 17.7 & \multicolumn{3}{|c|}{3.3} \\
\hline 504 & 524 & 12.5 & \multicolumn{3}{|c|}{2.5} \\
\hline 475 & 522 & 16.7 & \multicolumn{3}{|c|}{3.5} \\
\hline 466 & 516 & 14.6 & \multicolumn{3}{|c|}{3.1} \\
\hline & & & mean & 3.2 & $\hat{\sigma}=0.43$ \\
\hline
\end{tabular}

は 5〜6 $l$ を通した。これらの結果から，二酸化イオウ の槽準ガスではとの大部分はそのまま食篮層を通過する が，その 2.5〜3.8\%（壮 3.3\%) は嫶化水素ガスに 谓換されることがわか一た。この絬果だけでは，二酸化 イオウの一部が装臬内の微量の酸素扎よび水と反态し て，三酸化イオウあるいは硫酸ミストになり，加熱食塭 と反忘して塭化水素ガスを生じたのか，あるいは二酸化

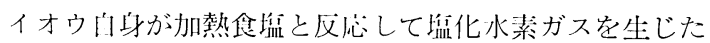
ものかは明以かにできなかった。しかし，一忘後者の理 川によるものよして ${ }^{38)} ，$ 酸化イオウの性 $3.3 \%$ は盐

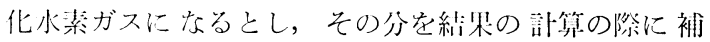
正与ることにした，末た，二酸化イオウ含星が $11 \mathrm{ppm}$
の標準ガス $18 l$ を加熱食塩中に通過させても, 吸収液 中にはそれによる塩素イオンは検出できなかった．これ は二酸化イオウが低濃度のときは，それが加熱食塩と反 応して盐化水素ガスを生ずる反応を無視してよいことを 示している.

\section{4 加熱食塩を用いる二酸化イオウと硫酸ミストの 分別定量}

$3 \cdot 1$ の方法で硫酸水素カリウムを加熱分解して $25 \mu \mathrm{eq}$ または $50 \mu \mathrm{eq}$ の三酸化イオウ（硫酸ミスト）を発生さ せ，これと二酸化イオウ標準ガスを用いて二酸化イオウ として $15 \mu \mathrm{eq}$ または 150〜500 $\mu \mathrm{eq}$ を混合し，その混 合物中の両者を分別定量したときの結果を Table III に 示した. Table III 中の全酸量とは，水酸化ナトリウム 標準溶液で $\mathrm{pH} 7$ まで中和滴定した值であり，これは 二酸化イオウ採取量之硫酸水素カリウムから生じた硫酸 ミスト量の $90.4 \%$ 分との和に相当する. Cl一量はモー ル法によって硝酸銀慓準溶液で滴定した值であり，これ は硫酸々スト発生量の $90.4 \%$ と二酸化イオウ採取量の $3.3 \%$ に相当する量との和にあたる.

Table III の $15 \mu \mathrm{eq}$ では二酸化イオウ含量 $11 \mathrm{ppm}$ の標準ガスを使用し，それを約 16〜18 $l$ 流した場合で あり，このときも二酸化イオウが低濃度であったため盐 化水素ガスの発生は無視できた. また, 試みに二酸化イ オウが $500 \mu \mathrm{eq}$ ぐらいまでの 塩化水素ガスへの転化率 を求めてみると, 硫酸の定量結果の誤差を無視すれば, 畃 3.8\% であり, Table II の結果とほぼ一致した.

Table III Differential determination of sulfur dioxide and sulfuric acid mist

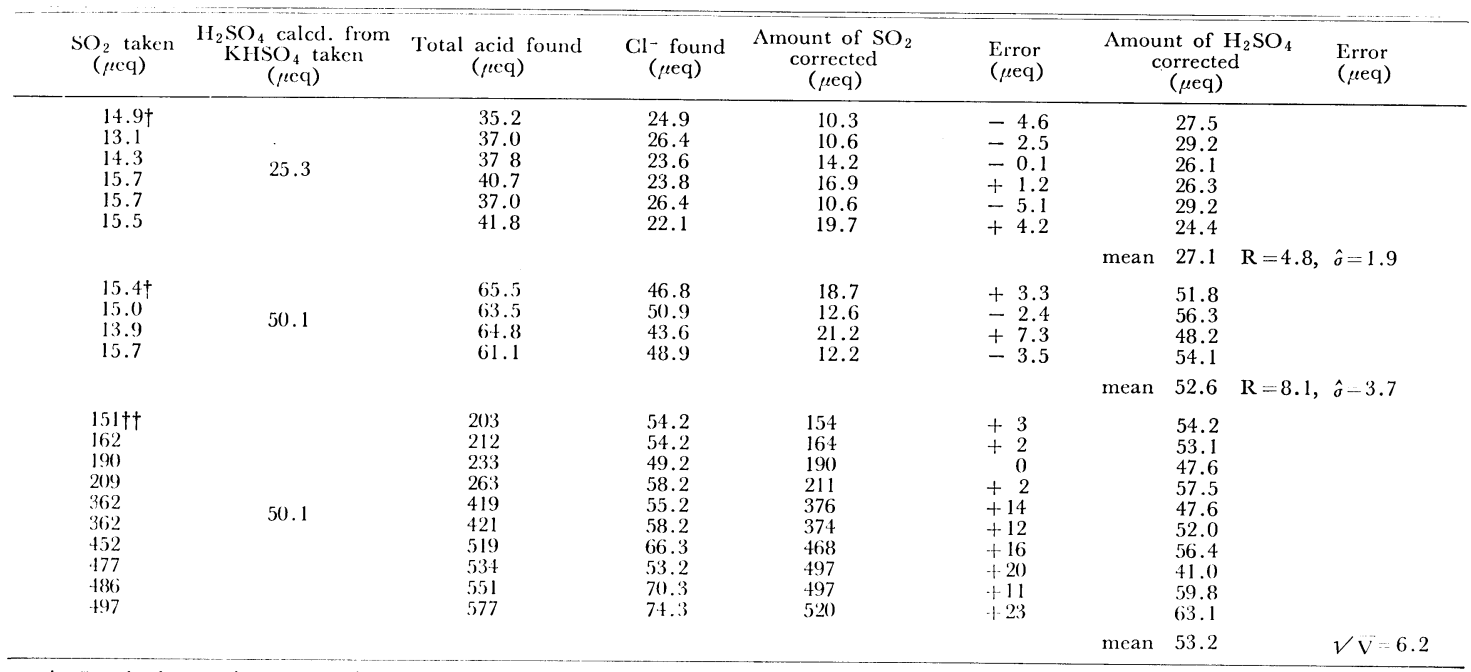

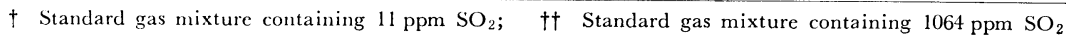


Table IV Differential determination of sulfur dioxide and the sulfuric acid mist in flue gas

\begin{tabular}{|c|c|c|c|c|c|c|c|c|c|c|}
\hline \multirow{3}{*}{ Furnace } & \multicolumn{8}{|c|}{ Heated sodium chloride method } & \multirow{2}{*}{\multicolumn{2}{|c|}{$\begin{array}{l}\text { Cottrell method } t \\
\mathrm{SO}_{2}+\mathrm{H}_{2} \mathrm{SO}_{4} \text { found }\end{array}$}} \\
\hline & \multirow{2}{*}{$\begin{array}{l}\text { Total acid } \\
\text { found } \\
(\mu \mathrm{eq})\end{array}$} & \multirow{2}{*}{$\begin{array}{l}\mathrm{Cl}^{-} \text {found } \\
\quad(\mu \mathrm{eq})\end{array}$} & \multicolumn{3}{|c|}{ Amount of $\mathrm{SO}_{2}$} & \multicolumn{2}{|c|}{ Amount of $\mathrm{H}_{2} \mathrm{SO}_{4}$} & \multirow{2}{*}{ 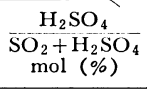 } & & \\
\hline & & & $(\mu \mathrm{eq})$ & $(\mathrm{ppm})$ & $\left(\mathrm{mg} / \mathrm{m}^{3}\right)$ & $(\mu \mathrm{eq})$ & $\left(\mathrm{mg} / \mathrm{m}^{3}\right)$ & & $(\mu \mathrm{eq})$ & $(\mathrm{ppm})$ \\
\hline Ore sintering & $\begin{array}{l}2460 \\
2240 \\
2300\end{array}$ & $\begin{array}{l}82.4 \\
116 \\
113\end{array}$ & $\begin{array}{l}2450 \\
2190 \\
2255\end{array}$ & $\begin{array}{l}1870 \\
1690 \\
1720\end{array}$ & $\begin{array}{l}5340 \\
4810 \\
4910\end{array}$ & $\begin{array}{l}10.0 \\
50.0 \\
45.0\end{array}$ & $\begin{array}{l}33.4 \\
168 \\
133\end{array}$ & $\begin{array}{l}0.4 \\
2.3 \\
1.8\end{array}$ & $\begin{array}{l}2420 \\
1850 \\
1840\end{array}$ & $\begin{array}{l}1398 \\
1158 \\
1171\end{array}$ \\
\hline Water boiler & $\begin{array}{l}209 \\
204 \\
197\end{array}$ & $\begin{array}{l}37.7 \\
35.6 \\
25.4\end{array}$ & $\begin{array}{l}176 \\
173 \\
177\end{array}$ & $\begin{array}{l}116 \\
115 \\
117\end{array}$ & $\begin{array}{l}330 \\
327 \\
334\end{array}$ & $\begin{array}{l}33.0 \\
31.0 \\
20.0\end{array}$ & $\begin{array}{l}94.8 \\
89.8 \\
57.9\end{array}$ & $\begin{array}{l}15.8 \\
15.2 \\
10.1\end{array}$ & $\begin{array}{l}205 \\
256\end{array}$ & $\begin{array}{l}126+t \\
156+t\end{array}$ \\
\hline
\end{tabular}

$\dagger$ Approximate value; i† Determined between the analyses by the sodium chloride method

Table III の後から 4 列めと 2 列めの二酸化イオウ量お よび硫酸量はそれらの塩化水素ガスへの転化率をそれぞ れ $3.3 \%$ および $90.4 \%$ として補正した結果で，次式に より計算した.

Total acid $(\mu$ eq $)=\mathrm{SO}_{2}(\mu$ eq $)+0.904 \mathrm{H}_{2} \mathrm{SO}_{4}(\mu$ eq $)$ $\mathrm{Cl}^{-}(\mu \mathrm{eq})=0.033 \mathrm{SO}_{2}(\mu \mathrm{eq}) *+0.904 \mathrm{H}_{2} \mathrm{SO}_{4}(\mu \mathrm{eq})$

以上のように多少の補正をすることによって，Table III 程度の二酸化イオウと硫酸 そストの混合ガス中のそ れぞれを分別定量できることがわかった。

\section{5 加熱食塩法による 煙道排ガス中の二酸化イオウ と硫酸ミストの分別定量}

4.4 で得た加熱食塩法を用いて，鉱石の焼結炉および ボイラー煙道排ガス中の二酸化イオウと硫酸ミストを分 別定量したときの結果を Table IV に示した。焼結炉 の排ガスを測定した場所は，湿式コットレル型電気集じ え装置で排ガス中のダストや硫酸ミストを除去したの ち，煙突へ通じる途中またはボイラー排ガスの煙突へ通 じる途中におけるいずれもダクトの位置であった．焼結 炉排ガスの場合は，加熱食塩法と Fig. 1 の装置を応用 した方法とで同時に測定したが，装置のつごうで後者の 方法においてはキャップ部を特に長くする必要があった ので完全な保温ができず，凝縮水が漏れたためにかなり 低值を得ることが尒想された。ボイラー排ガスの場合は 測定孔が一つしかなかったので同時には測定できなかっ た. Table IV の結果から, 時間带によっても異なるが， 焼結炉排ガス中の硫酸ミストをガス状とみなすと 7.6〜 $38.4 \mathrm{ppm}$ に相当する. また，全イオウ酸化物に対して 硫酸ミス卜は $0.4 \sim 2.3 \mathrm{~mol} \%$ （重量百分率で $0.6 \sim 3.3$ \%)であった．排ガスが湿式コットレル型霄父集じん装 置を通ったあとでも，この程度の硫酸ミストが検仙され た理由としては，硫酸ミストが集じえ装置で完全に除か
れなかったのか，あるいは集じん装置を通ったあとで排 ガス円の二酸化イオウが酸化鉄や水蒸父などによって酸 化され，硫酸ミストを生じたかのいずれかによると思わ れるが，それ以上の検討はできなかった．Fig. 1 に準じ た電気集じえ法で測定した全イオウ酸化物濃度は, 前述 の理由により低值を得たが，参考までに記した。

また，ボイラー排ガス中の硫酸ミストをガス状とみな すと，13.3 21.7 ppm に相当し，全イオウ酸化物量は 約 10〜 $16 \mathrm{~mol} \%$ （重量百分率で 15〜22\%）であった. 従来煙道排ガス中の三酸化イオウは全イオウ酸化物の 1〜5\% であると考えられてきたが，乙の結果はそれよ りもかなり多いように思われる。また，同時測定ができ なかったので塀密な意味では問題はあるが，Fig. 1 に準 じた電気集じえ法で测定した全イオウ酸化物の濃度は, 最後の測定值を除けばほぼ一致している.

いずれにせよここてで测定した煙道排ガスのような， イオウ酸化物量が多く，かつ比較的単純な組成のガスの 塨合には，本法はかなり有効な方法であるといえよう。

なお，本法に対する窒素酸化物の影響も一応考元られ るようであるが，これについては目下検討中である.

\section{5 総括}

一定量の三酸化イオウ（硫酸 こスト）を発生させるに は, 一定量の硫酸水素カリウムを $300^{\circ} \mathrm{C}$ 以下の温度か ら $800^{\circ} \mathrm{G}$ まで，徐々に加熱分解する方法が適当であっ た、一部では三酸化イオウの吸収剂として楜当といわれ ることもある $80 \%$ IPA は，实際には水または $1 \%$ 過 酸化水素水と同程度, あるいはとれ以下の吸収能力しか ないことがわかった。また，吸収溶媒に吸収されずに発 生した硫酸ミストは，特に高濃度でなければコットレル

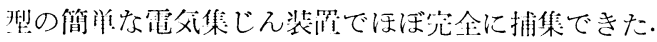

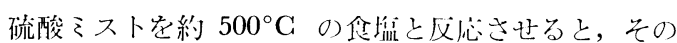
$90.4 \%$ が水に谷易に吸収される塩化水絜ガスに圆換さ れた。また，二酸化イオウも加熱食塩と反応してその 
$3.3 \%$ が塩化水素ガスに置換された．したがって，この 分を補正することによって二酸化イオウと硫酸そストと を分別定量できることがわかった．

この方法で実際に鉱石筧結炉やボイラー排ガス中の二 酸化イオウと硫酸るストを测定した.

(本会籘 20,21 年会および日本化 $)$

\section{交献}

1) P. F. Corbett : J. Inst. Fuel, 24, 247 (1951).

2) F. E. Blacet : Ind. Eng. Chem., 44, 1339(1952).

3) E. R. Gerhard, H. F. Johnstone : ibid., 47, 972 (1955).

4) H. F. Johnstone, D. R. Coughanowr : ibid., 50, 1169 (1958).

5) H. F. Johnstone, A. J. Moll : ibid., 52, 862 (1960).

6) R. S. Fielder, C. H. Morgan : Anal. Chim. Acta, 23, 538 (1960).

7) B. T. Commins : Analyst, 88, 364 (1963).

8) R. A. Mott, K. Parramore : J. Inst. Fuel, 30, 123 (1957).

9) P. H. Crumley, H. Howe, D. S. Wilson : ibid., 31, 378 (1958).

10) P. J. Jackson, W. E. Langdon, P. J. Reynolds : ibid., 43, 10 (1970).

11) A. W. Fletcher : Chem. Ind. (London), 28, 303 (1956).

12) D. W. E. Axford, T. M. Sugden : J. Chem. Soc., 1946, 901.

13) I. Steinke : Z. Anal. Chem., 244, 253 (1969).

14) E. Barendrecht, W. Martens : Anal. Chem., 34, 138 (1962).

15) J. R. Glass, E. J. Moore : ibid., 32, 1265 (1960).

16) L. E. Hibbs, D. H. Wilkins : Anal. Chim. Acta, 20, 344 (1959).

17) F. P. Scarringelli, K. A. Rehme : Anal. Chem., 41, 707 (1969).

18) J. H. Coste, G. B. Courtier : Trans. Faraday Soc., 32, 1198 (1936).

19) P. P. Mader, W. J. Hamming, A. Bellin : Anal. Chem., 22, 1181 (1950).

20) L. Dubois, C. J. Baker, T. Teichman, A. Zdrojewski, J. L. Monkman : Mikrochim. Acta, 1969, 269.

21) J. V. Kerrigan, K. Snajberk : Anal. Chem., 32, 1168 (1960).

22) D. Flint : J. Soc. Chem. Ind., 67, 2 (1948).

23) M. Hissink : J. Inst. Fuel, 36, 372 (1963).

24) P. F. Corbett : J. Soc. Chem. Ind., 67, 227 (1948).

25) R. S. Fielder, P. J. Jackson, E. Raask : $J$. Inst. Fuel, 33, 84 (1960).

26) E. B. Seidman : Anal. Chem., 30, 1680 (1958) .

27) I. G. Dobrochiver, N. Ya. Zuzykina, L. N. Shishkin, B. V. Osipov : Zavodsk. Lab., 38, 659 (1972); Anal. Abstr., 24, 39 (1973).

28) A. W. Fletcher : Chem. Ind. (London), 27, 777 (1954).
29）山本憲子，渡辺 彰，中村富忠，柳沢三郎：本 誌, 19, 834 (1970).

30) H. W. Danser : Chem. Eng., 57, 158 (1950).

31) G. F. Goodeve : Trans. Faraday Soc., 32, 1218 (1936).

32）日本分析化学会関東支部編：“公害分析指針・大 気編 $2 \mathrm{~b} ”$, p. 38 (1972), (共立出版).

33）木村菊二, 多田 治, 肝付邦憲, 中明賢二 : 労働 科学，41，501 (1965).

34) 吉森孝良, 野々村誠：本誌，21，813 (1972).

35) W. F. Hillebrand, G. E. F. Lundell, H. A. Bright, J. I. Hoffman : "Applied Inorganic Analysis", 2nd Ed., p. 178 (1953), (John Wiley, New York).

36) JIS K 0103 (1963).

37）大気污染研究全国協議会編 : “大気污染ハンドブ ック”，(4) 燃焼編，p. 457(1969)，(コロナ社).

38) Gmelin-Institut : "Gmelins Handbuch der anorganischen Chemie, Chlor', 8 Aufl., S. 98 (1927).

39）武者宗一郎, 額田正巳, 岡野利昌, 札野新太郎, 水谷 勝 : 本誌, 18, 349 (1969).

40) 昆野信也，山本憲子，柳沢三郎：同上， 20，102 (1971).

$$
\text { 누․ }
$$

Differential determination of sulfur dioxide and sulfuric acid mist by using heated sodium chloride. Takayoshi Yoshimori and Makoto NonoMURA (Science University of Tokyo, Faculty of Engineering, 1-3, Kagurazaka, Shinjuku-ku, Tokyo)

Since a mist of sulfuric acid reacts with heated sodium chloride producing hydrogen chloride whereas sulfur dioxide does not virtually, the process was used for the differential determination of a mixture of them. The sample mixture was allowed to react with sodium chloride at about $500^{\circ} \mathrm{C}$, and the resulting product was introduced into a $1 \%$ solution of hyrdogen peroxide. Both hydrochloric and sulfuric acids thus produced were determined alkalimetrically and argentometrically.

In order to produce the definite amount of a mist of sulfuric acid, the following method was recommendable. An aliquot of a standard solution of potassium hydrogen sulfate was taken in a platinum boat, and was evaporated to dryness. Then the boat was placed in a silica tube heated at about $300^{\circ} \mathrm{C}$, and the temperature of the tube was raised gradually up to $800^{\circ} \mathrm{C}$. Pure nitrogen was used as the carrier gas of the mist. As a source of sulfur dioxide, a standardized gas mixture of the dioxide and nitrogen were preferable, and were also utilized as the carrier gas of the mist.

The absorbent of sulfuric acid mist was preliminarily investigated in conjunction with the usefulness of potassium hydrogen sulfate as the standard for the production of the mist (Table I). An aqueous solution of $80 \%$ isopropanol which was sometimes preferred as the absorbent of the mist was not recommendable. As Fig. 1 shows, a combination of the aqueous solution of $1 \%$ hydrogen peroxide with the electrostatic precipitator was most satisfactory for the complete absorption of the mist. About $30 \sim 60 \%$ of the mist was 
deposited on the inner surface of the "cap" in Fig. 1. No effective absorption of the mist could be expected by any solution used.

The reactions both sulfuric acid mist and sulfur dioxide with heated sodium chloride were next investigated. Ninety per cent of the mist and 3.3\% of the dioxide were converted to hydrogen chloride by the reaction at $500^{\circ} \mathrm{C}$ (Table II). These values were used to correct the results of the titrations. It was considerable to be the reason for the lower results from the mist that sodium hydrogen sulfate was produced and was not decomposed completely at the reaction temperature. The conversion ratio of the dioxide was negligible if the dioxide content was small. The mixtures of the mist and the dioxide were analyzed by this method with satisfactory results (Table III).

This method was applied to analyze the mist and the dioxide in the flue gases produced at an ore-sintering furnace and a water boiler furnace by using the apparatus illustrated in Fig. 2, and the results obtained were shown in Table IV.

(Received Aug. 31, 1973)

\title{
フレームを用いない原子吸光分析
}

\author{
柳沢雅明，武内次大**
}

(1973 年 9 月 4 日受理)

\begin{abstract}
フレームを用いない原子吸光分析法における電気抵抗発熱材料としてガラス状荻素を脂い，氾の们效 性を検討した。用いたガラス状炭素は $0.7 \mathrm{~mm}$ 厚， $45 \mathrm{~mm}$ 長，および $2.5 \mathrm{~mm}$ 幅の薄板で，2本の ステンレス鋼製電極に取り付け，取りはずし可能なパイレックスガラス製の谷器（三少は不英ガラス 空，内容積約 $350 \mathrm{~m} l$ ) に格納し，内部の父体はアルゴンあるいはアルゴンー水装ガスを流して置換し た。原子吸光測定には細光束が有効で，これにより感度が增大し，かつ狄い領域の测分ができた。侙料 の化学組成の違いによる差，および共存する他種元菜による影響が観察された。

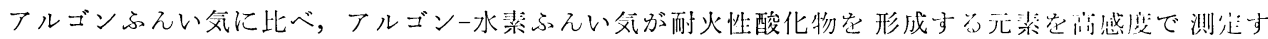
るのにきわめて効果的であった。
\end{abstract}

\section{1 緒}

比報1)2）において，タンタル金属あるいはグラフォイ 卜棒を電気加熱する方法による試料原子化の挙動を報告 した，本研究では，分析化学的にも利用されて扮り，種 種の興味ある特性をもつガラス状炭素を電気抵抗発熱体 とするフレームを用いない試料原子化装置を開発し，そ の原子吸光特性を検討した。

現在，この分野でガラス状炭素を応用した研究はほと えどみられない3.

\section{2 笑駼}

\section{1 装}

日本ジャーレルフッシュ社 $\mathrm{AA}-1 \mathrm{E}$ 型原子吸光・炎光 共用分光分析装置で，原子化部にガラス状炭素㴓板定化 気抵抗発熱体とする原子化装置 (Fig. 1) 号取り付けて优

* 名古屋大学工学部合成化学科 : 愛知赑名古屋师千租 区不老町
用した。光源には门贩中空除極ランプ (Westinghouse, 日立社）および試作細口径中空㓌極ランプ（浜松テレビ 社, 㓌極直径約 $2 \mathrm{~mm}$ ) を礼い, パルス点登 $(60 \mathrm{~Hz})$ 乙 た。記録には日立 QPD-54 型记録計を，光高洫部は北 辰電機 $201 \mathrm{~N} 1$ 型を用いた。藏料溶液採取にはオースト ラリア S. G. E. 社 $5 \mu l$ マイクロシリンジを用いた。

\section{2 試料溶液}

金属銅，鉛（99.9\% 以上）在特級硝酸に溶解し，1 $\mathrm{mg} / \mathrm{ml}$ の溶液を调製した。粡の場介は，この溶液から

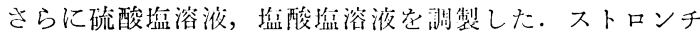
ウム溶液は岑酸埝を塩酸に溶解して $1 \mathrm{mg} / \mathrm{ml}$ の溶液と した。これらはいずれも使月直阙に希秋して使用した。

嫶化アルミニウム打よび倎化ナトリウム溶液（1 mg/ $\mathrm{m} l)$ は，金属アルミニウム，塭化ナトリウムより塩酸 溶液を調製した。

\section{3 操 作}

アルゴンあるいはアルゴンー水杪老一这流速で流し ながら，计料溶液を $5 \mu l$ マイクロシリンジを朋いてガ 